\title{
Environmental Impact Assessment of the Life Cycle of a Timber Building
}

\author{
D.N. Kaziolas ${ }^{1}$, I. Zygomalas ${ }^{2}$, G.E. Stavroulakis ${ }^{3}$ and C.C. Baniotopoulos ${ }^{4}$ \\ ${ }^{1}$ Technological Educational Institute of Kavala, Kavala, Greece \\ ${ }^{2}$ Institute of Metal Structures, Department of Civil Engineering \\ Aristotle University of Thessaloniki, Thessaloniki, Greece \\ ${ }^{3}$ Institute of Computational Mechanics and Optimization, Department of Production Engineering \& \\ Management, Technical University of Crete, Chania, Greece \\ ${ }^{4}$ Institute of Metal Structures, Department of Civil Engineering \\ Aristotle University of Thessaloniki, Thessaloniki, Greece \\ and Chair of Sustainable Energy Systems, School of Civil Engineering \\ The University of Birmingham, United Kingdom
}

\begin{abstract}
Timber construction offers a number of advantages in terms of sustainability in comparison with other construction technologies. This can partly be attributed to the fact that structural timber products often require less processing for their manufacturing compared to other construction products and their sustainability is therefore relatively increased. As a result, structures such as timber buildings are associated with increased sustainability potential and are therefore selected as sustainable solutions for the construction of housing, commercial or other types of building projects. The current research, described in this paper, is aimed at the quantification of the environmental impact caused by the construction of timber buildings. A case study is used as the basis for the calculations which take into account the whole life cycle of the timber building examined. A life cycle assessment is conducted and the environmental impact assessment results are calculated according to the Eco-Indicator 99 methodology. The interpretation of the results leads to conclusions regarding the level and type of environmental impact caused by the life cycle of timber building projects.
\end{abstract}

Keywords: timber structures, timber buildings, environmental impact, life cycle assessment.

\section{Introduction}

The movement for sustainable development aims at the optimization of the whole of human activity in terms of environmental, economic and social impact. Thus, it has become one of the priorities of the whole world, fact that is proved from the plethora of relevant events such as United Nations conferences and reports [1, 2]. This goal is achieved through the adoption of solutions that will ensure the future of next generations without the need of conciliation. As an upshot, this goal attracted the interest of many researchers dealing with the development of methodologies that 
reduce the environmental impact caused by all business sectors and especially by the construction sector. The latter is the largest sector in the world that is responsible for the consumption of vast amounts of raw materials and energy, while it also produces significant quantities of waste [3]. Traditional construction materials and techniques such as concrete do not hold adequate potential in terms of minimization of environmental impact while steel and timber construction present increased opportunities in regard to environmental sustainability due to their potential for retrieving, recycling and reuse after the decision for demolition has been made.

Many methodologies have been developed for the quantification of the environmental impact of construction projects, while the most widely known and used is Life Cycle Assessment (LCA) [4]. Although LCA was developed for other types of products, its efficiency has led to its utilization in construction projects [5]. LCA has four interdependent phases: goal and scope definition; life-cycle inventory (LCI); life-cycle impact assessment (LCIA) and interpretation. The environmental impact assessment results by LCA are calculated by some methods like impact 2002+, CML 2001, EPS 2000, and Eco-indicador'99. The realization of the LCA for timber structures is achieved by the use of suitable software like $\mathrm{GaBi}$ [6] or SimaPro. LCA is a method for quantifying the environmental impact of the lifecycle of individual products or services from cradle to grave and it is the most important method for assessing the overall environmental impact of products from design to disposal. Nevertheless, till now, the environmental sustainability for timber construction and the potential of its life-cycle is not completely explored. LCA of timber construction has to take into account, among others, during the analysis, many data; forest harvesting and processing, the role of wood as both material and fuel, the fact that the trees store $\mathrm{CO}_{2}$ in their tissues that is released by the decomposition of wood which happens at the end of life of it $[7,8]$.

Wood is a material that requires a lower processing power in order to be prepared for building construction in comparison with most common construction materials like concrete. During the process of "manufacturing" the wood for use in the construction sector there is no waste, after the "waste" can be used for derivative products of wood or fuel, with result the decreasing of the demand for fossil fuels. Partial displacement and repairing is feasible in a timber building without jeopardised the safety and operation of the whole structure. Fossil fuel consumption, contributions to GHG emissions and quantities of solid waste are less for manufacturing a building by wood than by other materials [9]. A timber building has lower environmental burdens than buildings made of other materials [10]. The timber buildings present increased energy efficiency since wood has thermal conductivity. After demolishing a timber structure the wood can be retrieved for use in new timber buildings or can be used as raw material for the production of woodbased products or as a fuel. In case that wood goes to recycling to landfills, it is biodegradable and does not constitute any kind of environmental threat [11].

This research deals with the examination of the potential of timber construction and the quantification of the environmental impact caused by its application. An existing timber truss construction is used as case study and a LCA is conducted taking into account issues such as raw material acquisition, construction and waste management, recycling. The latter is applied by means of SimaPro software and the 
environmental impact assessment results are calculated by Eco-indicator 99 method [12].

\section{Methodology}

The building which is selected as the basis for the calculations of the environmental impact caused throughout the life cycle of timber buildings is a ground-floor industrial building constructed of a series of timber load-bearing frames as displayed in Figures 1 and 2a, 2b.

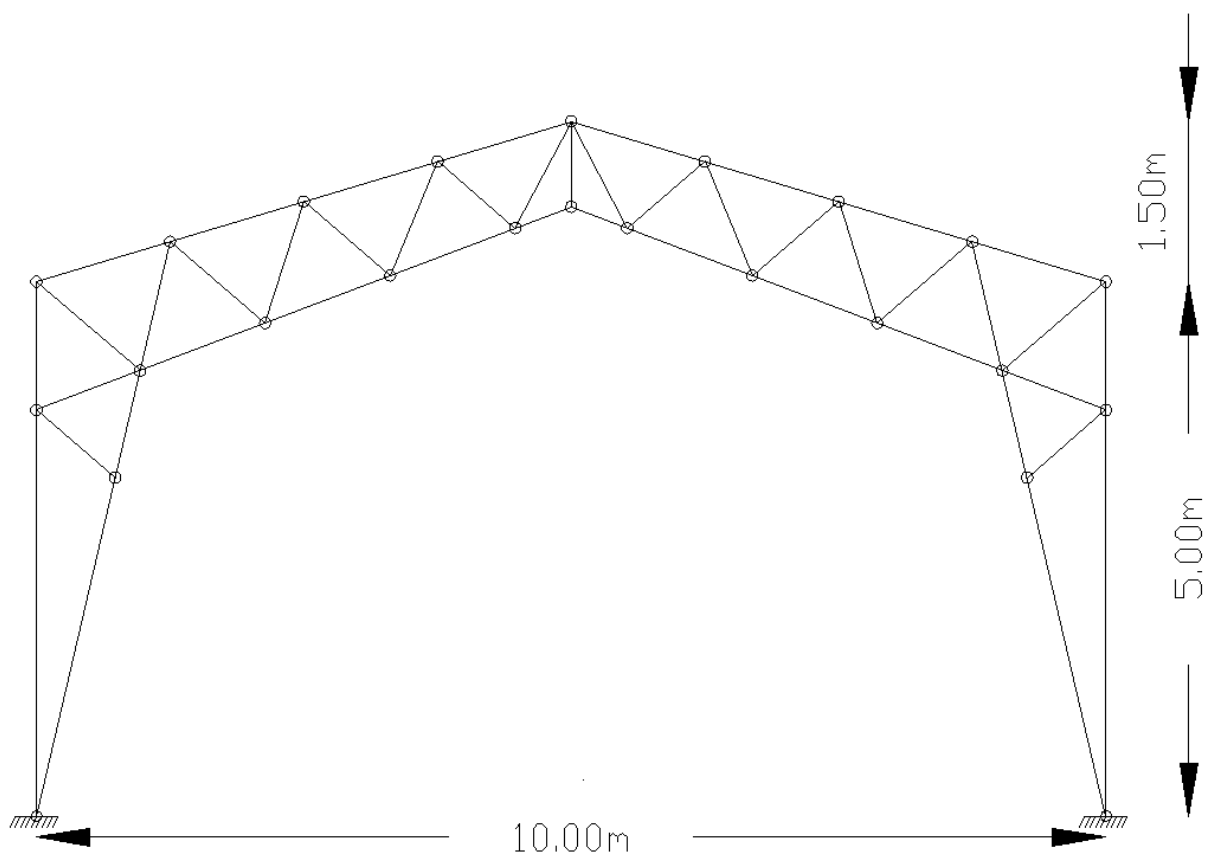

Figure 1: Timber load-bearing frame

Life cycle assessment (LCA) is used to quantify the environmental impact associated with each stage of the building's life cycle. Based on the quantities of materials required for the construction of the selected building, the LCA analysis is conducted using environmental data as made available in existing life cycle inventory (LCI) databases such as the Ecoinvent LCI database. The materials required for the construction of the timber building that were taken into account are resented in Table 1.

\begin{tabular}{llr}
\hline Construction materials & Unit & Quantity \\
\hline Structural timber (pine wood) & $\mathrm{m}^{3}$ & 22.54 \\
Roof covering panels (steel) & $\mathrm{m}^{2}$ & 156.60 \\
Wall panels (steel) & $\mathrm{m}^{2}$ & 265.00 \\
\hline
\end{tabular}

Table 1: Main materials required for the construction of the timber building 


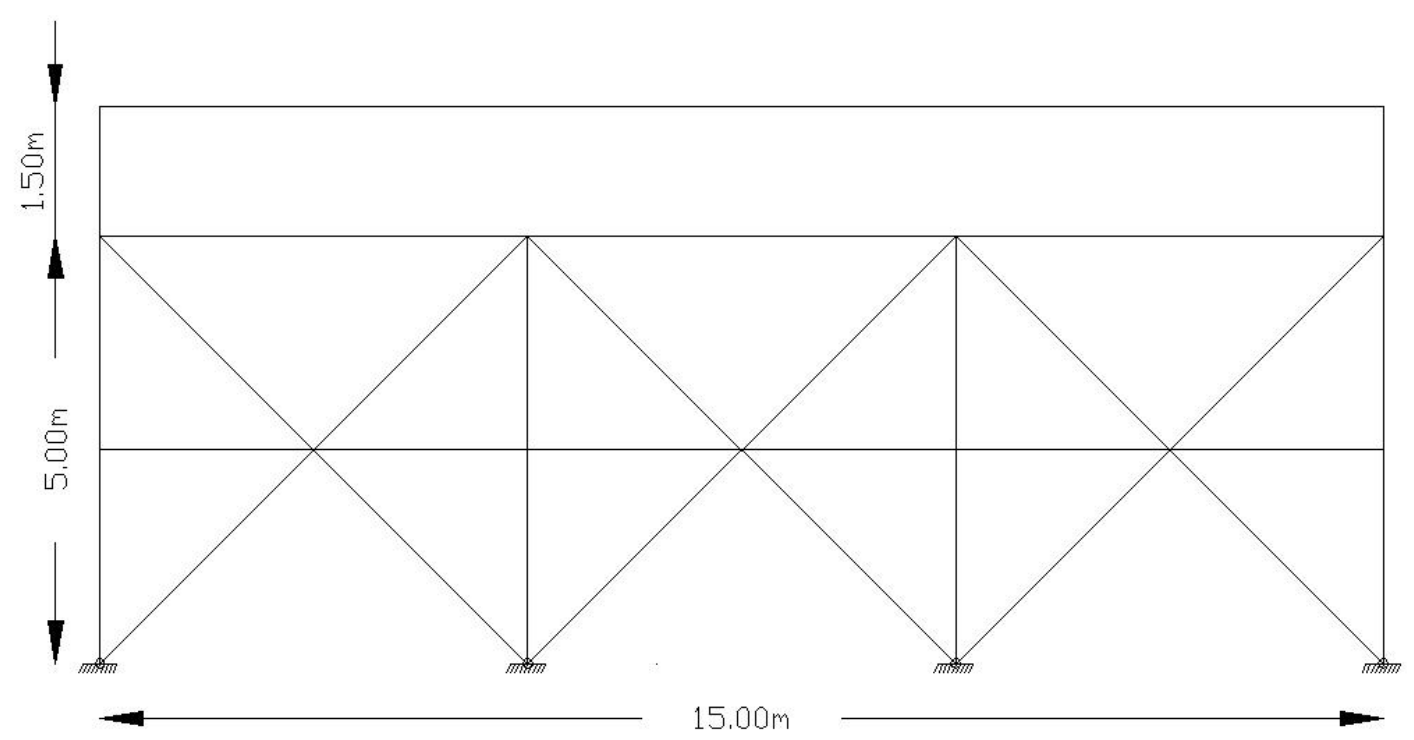

Figure 2a: Side view of timber building

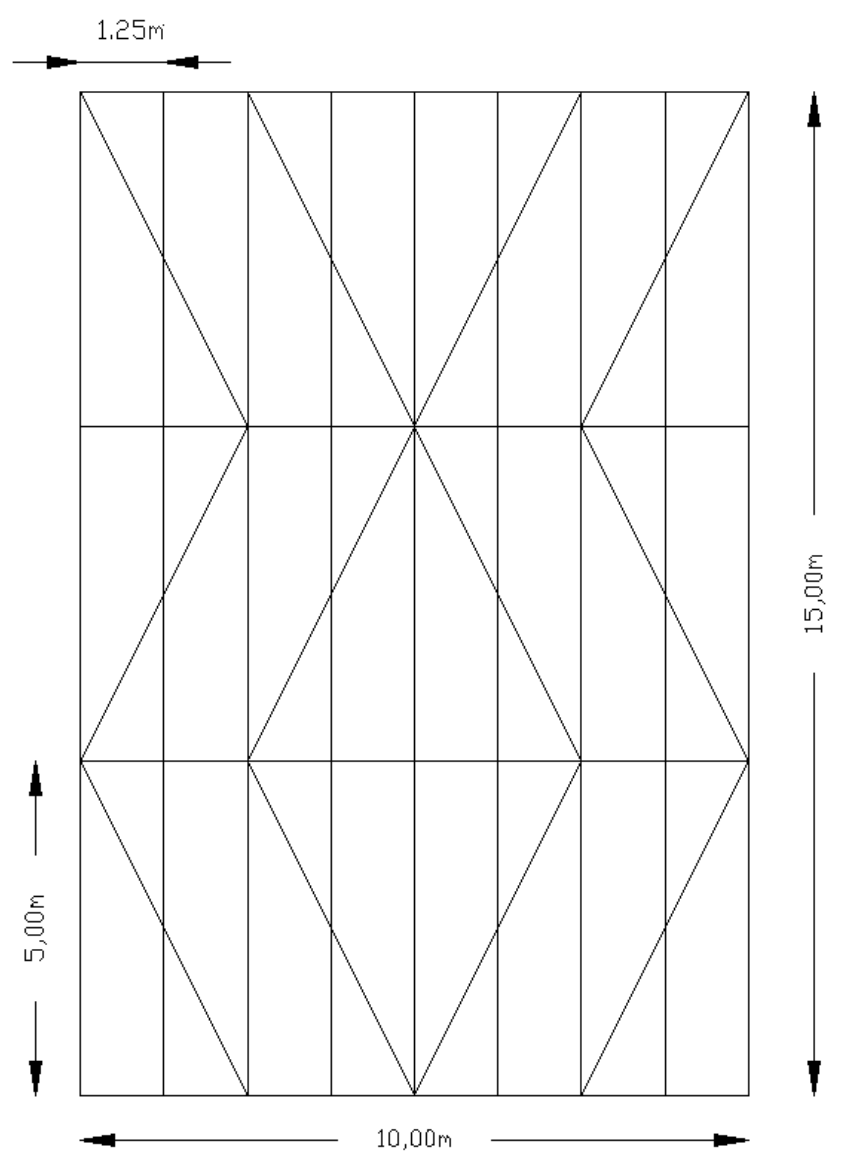

Figure 2b: Plan view of timber building 


\subsection{Goal, scope and functional unit}

The goal of the current LCA analysis is the calculation of the environmental impact caused throughout the life cycle of the examined timber building. As the purpose of the research is to investigate the sustainability potential of timber as a construction material, the stages of the building's life cycle that are taken into account are selected accordingly, so as to enable the provision of results directly related to the quantity of timber used. The stages taken into account include the acquisition of the raw materials and energy required for the manufacturing of the building's components, the transport of the building materials to the site and their handling at the end of the building's service life.

The distance taken into account for the transport of the timber materials to the site is $50 \mathrm{~km}$, based on the assumption that it is not always possible to use local materials in the case of timber. In regard to the rest of the materials a $10 \mathrm{~km}$ transport distance is assumed as they can usually be acquired from local suppliers or manufacturers.

The functional unit for the LCA analysis is the construction of one timber building according to the aforementioned specifications. As the analysis refers to the conditions surrounding timber structures in Greece, the geographic coverage of the LCA is initially the Greek region but could also be generalized for the wider European region.

\subsection{End scenarios}

As one of wood's most important properties in terms of its sustainability as a construction material is its potential for recycling or reuse, a set of end scenarios was developed for the current LCA analysis. In specific, three end scenarios were assumed, each corresponding to a different way of handling the retrieved materials at the end of the timber building's service life and after the decision for demolition has been made. The first scenario refers to the recycling of the retrieved timber components, the second one to their reuse and the third to their incineration. All three end scenarios were developed with the aim to quantify the environmental impact of each waste treatment and therefore clearly display their sustainability potential. The assumptions taken into account for each end scenario are presented in Table 2. It is also noted that in regard to the cladding materials used for the construction of the timber building, the same waste treatments are taken into account for all three end scenarios. A $100 \mathrm{~km}$ distance is assumed for the transport of the retrieved materials to the various end-of-life faculties at the end of the timber building's service life. 


\begin{tabular}{|c|c|}
\hline End scenario & Waste treatment \\
\hline Recycling & $\begin{array}{l}80 \% \text { of timber recycled, } 20 \% \text { considered } \\
\text { irretrievable and disposed in landfill } \\
90 \% \text { of cladding materials recycled, } 10 \% \\
\text { considered irretrievable and disposed in landfill }\end{array}$ \\
\hline Reuse & $\begin{array}{l}80 \% \text { of timber reused, } 20 \% \text { considered } \\
\text { irretrievable and disposed in landfill } \\
90 \% \text { of cladding materials recycled, } 10 \% \\
\text { considered irretrievable and disposed in landfill }\end{array}$ \\
\hline Incineration & $\begin{array}{l}80 \% \text { of timber incinerated, } 20 \% \text { considered } \\
\text { irretrievable and disposed in landfill } \\
90 \% \text { of cladding materials recycled, } 10 \% \\
\text { considered irretrievable and disposed in landfill }\end{array}$ \\
\hline
\end{tabular}

Table 2: End-of-life scenarios developed for the handling of the retrieved materials

\section{Life cycle inventory (LCI)}

The results obtained from the LCA analysis of the life cycle of the timber building include a detailed list of environmental inputs and outputs, referring to the consumption of raw materials and energy (inputs) and the emission of substances to the air, water and soil or as waste (outputs). A selection of the most important environmental inputs and outputs is presented in Table 3 for the life cycle of the timber building and for each end-of-life scenario. The negative values refer to environmental benefits rather than burdens, which are derived from the effective handling of materials at the end scenarios, for example, recycling.

\section{Life cycle impact assessment (LCIA)}

The substances listed as environmental inputs and outputs are used as the basis for the calculation of environmental impacts in a set of specific categories or environmental indicators. The impact assessment methodology used is the EcoIndicator 99 methodology (Eco-indicator 99 (E) V2.08 / Europe EI 99 E/E) which covers a wide range of environmental aspects related to human, health, natural resources and the quality of the eco-system. The environmental impact of the main construction materials required for the construction of the timber house as well as the impact of their transport to the site and to the various end-of-life facilities (recycling plants, etc.) are displayed in Figure 3. It is noted that the environmental impact results presented are in Eco-Indicator 99 Points $(\mathrm{Pt})$ where $1 \mathrm{Pt}$ is representative of one thousandth of the yearly environmental load of one average European inhabitant. 


\begin{tabular}{|c|c|c|c|c|c|}
\hline Substance & Category & Unit & $\begin{array}{r}\text { Life cycle } \\
\text { (recycling) }\end{array}$ & $\begin{array}{r}\text { Life cycle } \\
\text { (reuse) }\end{array}$ & $\begin{array}{r}\text { Life cycle } \\
\text { (incineration) }\end{array}$ \\
\hline Coal (brown, in ground) & Raw material & $\mathrm{kg}$ & $-41,6202$ & $-41,6202$ & $-39,1512$ \\
\hline Dolomite $\left(\mathrm{CaCO}_{3}\right.$, in ground) & Raw material & $\mathrm{kg}$ & 0,003662 & 0,003658 & 0,016711 \\
\hline $\begin{array}{l}\text { Iron ( } 46 \% \text { in ore, } 25 \% \text { in } \\
\text { crude ore, in ground) }\end{array}$ & Raw material & $\mathrm{kg}$ & $-1842,02$ & $-1843,22$ & $-1836,61$ \\
\hline $\begin{array}{l}\text { Manganese (Mn, } 35.7 \% \text { in } \\
\text { sedimentary deposit, } 14.2 \% \\
\text { in crude ore, in ground) }\end{array}$ & Raw material & $\mathrm{kg}$ & $-0,01318$ & $-0,01318$ & $-0,01191$ \\
\hline Oil (crude, in ground) & Raw material & $\mathrm{kg}$ & 46,63425 & 46,63425 & 52,51164 \\
\hline $\begin{array}{l}\text { Water (unspecified natural } \\
\text { origin) }\end{array}$ & Raw material & $\mathrm{m}^{3}$ & $-12,5059$ & $-12,5059$ & $-12,228$ \\
\hline Zinc (Zn, in ground) & Raw material & $\mathrm{kg}$ & 0,000377 & $7,54 \mathrm{E}-05$ & 0,000377 \\
\hline Carbon dioxide $\left(\mathrm{CO}_{2}\right)$ & Air emission & $\mathrm{kg}$ & 5907,67 & 5907,67 & 5907,67 \\
\hline Carbon dioxide, fossil $\left(\mathrm{CO}_{2}\right)$ & Air emission & $\mathrm{kg}$ & $-1640,47$ & $-1640,47$ & $-1578,81$ \\
\hline Carbon monoxide (CO) & Air emission & $\mathrm{kg}$ & 37,0481 & 37,0481 & 37,0481 \\
\hline $\begin{array}{l}\text { Carbon monoxide, fossil } \\
\text { (CO) }\end{array}$ & Air emission & $\mathrm{kg}$ & $-40,4427$ & $-41,441$ & $-40,2547$ \\
\hline Dinitrogen monoxide $\left(\mathrm{N}_{2} \mathrm{O}\right)$ & Air emission & $\mathrm{kg}$ & 0,014226 & 0,011374 & 0,041183 \\
\hline Hydrogen Chloride (HCl) & Air emission & $\mathrm{kg}$ & 0,090856 & 0,090147 & 0,091885 \\
\hline Hydrogen Sulphide $\left(\mathrm{H}_{2} \mathrm{~S}\right)$ & Air emission & $\mathrm{kg}$ & $-0,02458$ & $-0,02476$ & $-0,02411$ \\
\hline Lead $(\mathrm{Pb})$ & Air emission & $\mathrm{kg}$ & 0,004256 & 0,004243 & 0,004302 \\
\hline Mercury (Hg) & Air emission & $\mathrm{kg}$ & $-8,4 \mathrm{E}-05$ & $-8,6 \mathrm{E}-05$ & $-7,6 \mathrm{E}-05$ \\
\hline Methane $\left(\mathrm{CH}_{4}\right.$, fossil $)$ & Air emission & $\mathrm{kg}$ & $-7,54034$ & $-7,54034$ & $-7,40993$ \\
\hline Nitrogen oxides $\left(\mathrm{NO}_{\mathrm{x}}\right)$ & Air emission & $\mathrm{kg}$ & 8,41582 & 7,56962 & 10,75701 \\
\hline $\begin{array}{l}\text { Non-methane volatile organic } \\
\text { compounds (NMVOC) }\end{array}$ & Air emission & $\mathrm{kg}$ & 2,548061 & 2,155503 & 2,973164 \\
\hline Particulates, < 2.5 um $\left(\mathrm{PM}_{2,5}\right)$ & Air emission & $\mathrm{kg}$ & $-1,24735$ & $-1,25496$ & $-1,19471$ \\
\hline Particulates, $<10$ um $\left(\mathrm{PM}_{10}\right)$ & Air emission & $\mathrm{kg}$ & 0,000652 & 0,00013 & 0,000652 \\
\hline Sulfur dioxide $\left(\mathrm{SO}_{2}\right)$ & Air emission & $\mathrm{kg}$ & $-3,88892$ & $-4,05091$ & $-3,81207$ \\
\hline Sulfur oxides $\left(\mathrm{SO}_{\mathrm{x}}\right)$ & Air emission & $\mathrm{kg}$ & 12,37607 & 12,37607 & 12,37607 \\
\hline Zinc $(Z n)$ & Air emission & $\mathrm{kg}$ & $-0,00048$ & $-0,0005$ & $-0,00038$ \\
\hline Cadmium, ion & Water emission & $\mathrm{kg}$ & $-9,6 E-05$ & $-9,6 \mathrm{E}-05$ & $-4,4 \mathrm{E}-05$ \\
\hline $\begin{array}{l}\text { Chemical Oxygen Demand } \\
\text { (COD) }\end{array}$ & Water emission & $\mathrm{kg}$ & 173,4805 & 173,4587 & 236,3872 \\
\hline Chromium, ion & Water emission & $\mathrm{kg}$ & $8,82 \mathrm{E}-06$ & $7,11 \mathrm{E}-06$ & $2,67 \mathrm{E}-05$ \\
\hline Iron & Water emission & $\mathrm{kg}$ & 1,645044 & 1,594652 & 1,645044 \\
\hline Lead (Pb) & Water emission & $\mathrm{kg}$ & 0,062346 & 0,062327 & 0,075905 \\
\hline Nickel, ion & Water emission & $\mathrm{kg}$ & $-0,06377$ & $-0,06377$ & $-0,058$ \\
\hline Suspended solids & Water emission & $\mathrm{kg}$ & $-0,41947$ & $-0,41947$ & $-0,4066$ \\
\hline Zinc, ion & Water emission & $\mathrm{kg}$ & $-0,03059$ & $-0,03059$ & $-0,02473$ \\
\hline Calcium & Soil emission & $\mathrm{kg}$ & 0,00161 & 0,001597 & 0,002434 \\
\hline Heat, waste & Soil emission & MJ & 151,357 & 151,357 & 152,2174 \\
\hline Iron & Soil emission & $\mathrm{kg}$ & $-0,0604$ & $-0,0604$ & $-0,0584$ \\
\hline Oils, unspecified & Soil emission & $\mathrm{kg}$ & 0,065438 & 0,065438 & 0,079995 \\
\hline
\end{tabular}

Table 3: Environmental inputs and outputs of the life cycle of the timber building for each end scenario

As can be observed, the largest environmental impacts are caused by the steel roof and wall panels which are used as cladding materials for the timber building. As expected, the structural timber used for the construction of the load-bearing frame of the building cause a much smaller impact. This can be attributed to the fact that structural timber elements require minimum processing in comparison to other construction materials such as steel or concrete. Without the need for significant manufacturing processes that require additional raw materials and energy, wood is almost directly cut into the final structural product which is then sent for use in 
construction projects. As a result, the environmental impact caused by its manufacturing is considerably minimized. It is therefore shown that timber construction holds a significant advantage; the environmental impact of timber materials is significantly lower than other construction materials. It is therefore suggested that timber products should be used in as many instances as possible within construction projects, as their utilization decreases the total environmental impact, subsequently increasing the overall sustainability of the project.

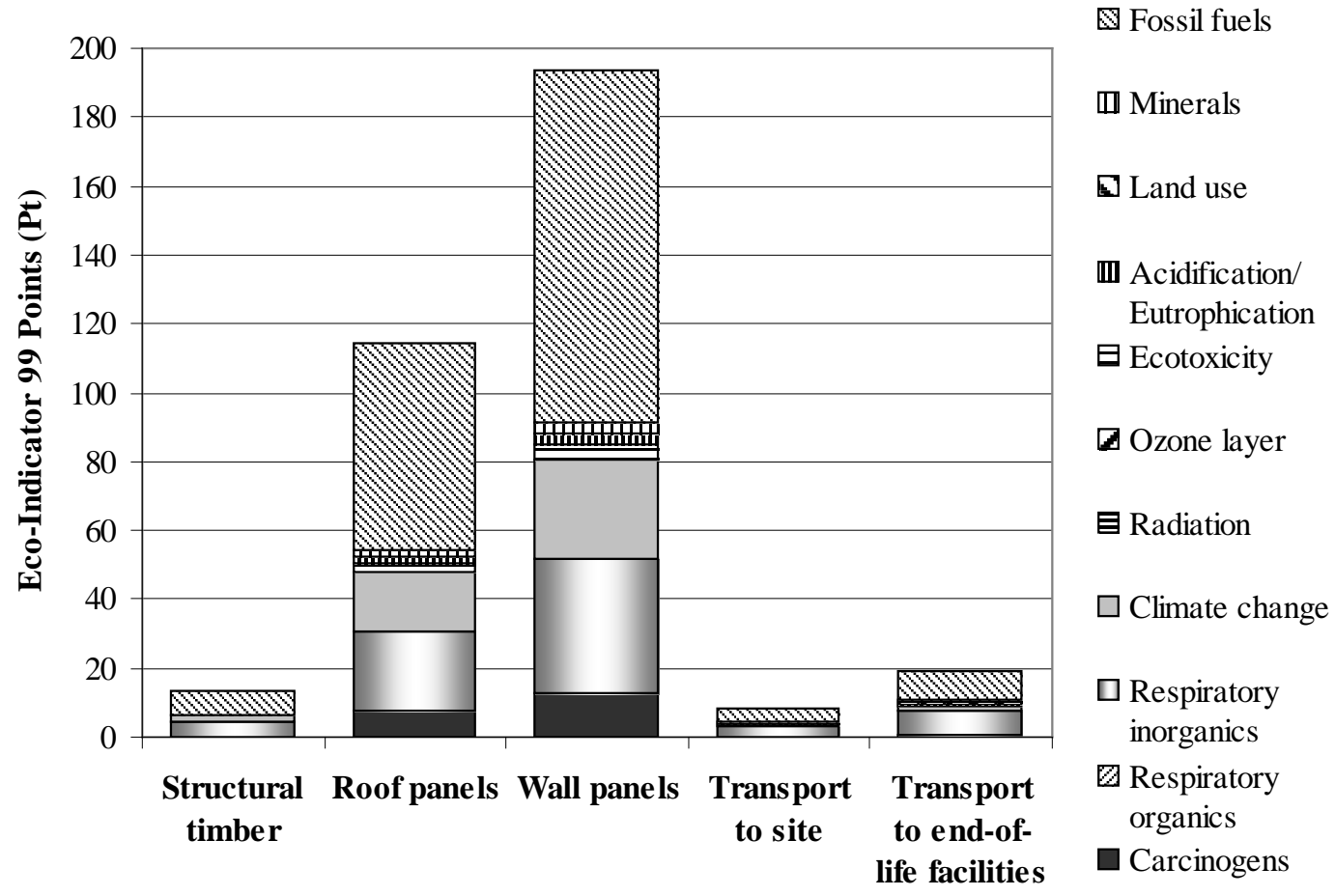

Figure 3: Environmental impact of the main construction materials and their transport

The transport of the materials to the site causes an even smaller environmental impact, while their transport to the end-of-life facilities when the service life of the timber building has ended causes a relatively higher impact, due to the increased distance taken into account.

In regard to the type of environmental impact caused, it is the 'fossil fuels' environmental indicator which refers to the quality of natural resources that is mainly burdened. Human health is also negatively affected ('respiratory inorganics' indicator), followed by 'climate change' which is mainly burdened from the manufacturing of the steel wall and roof panels.

These results refer to the main materials and processes required for the construction of the timber building. In order to examine the environmental impact of the end scenarios in relation to these materials and processes, they are grouped together and directly compared to the impact of each end scenario. This comparison is displayed in Figures 4 and 5. 


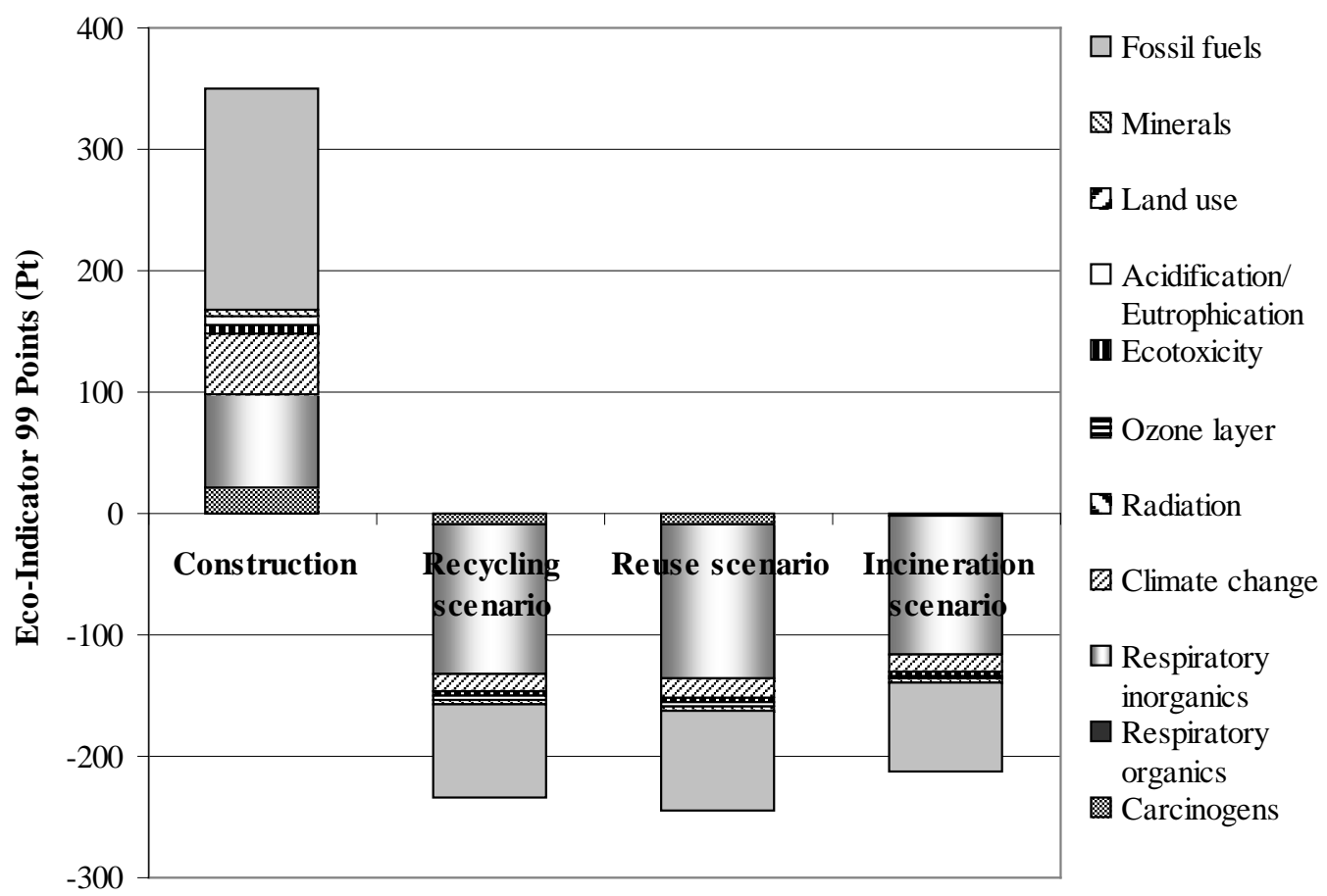

Figure 4: Environmental impact of the construction and end scenarios of the timber building

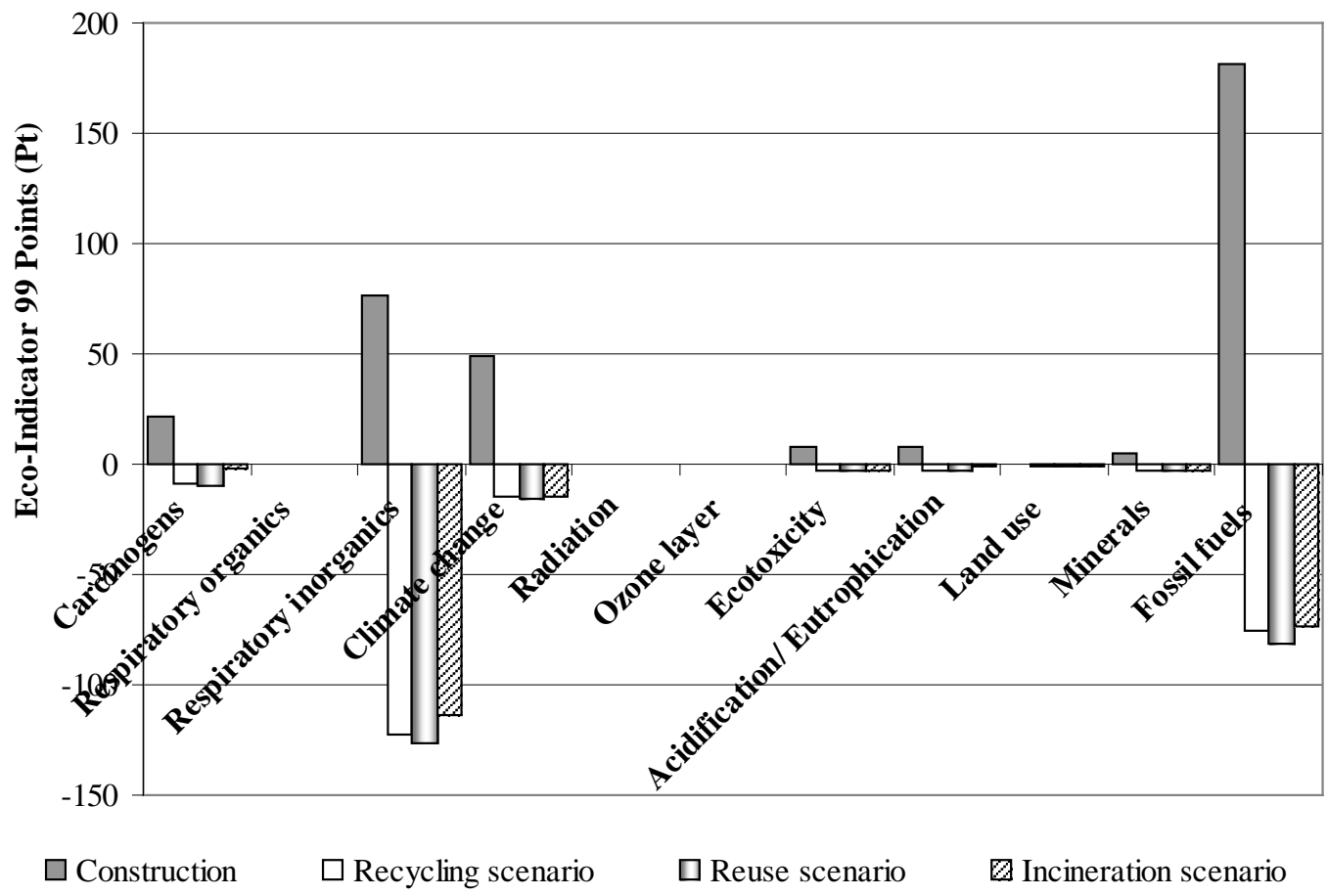

Figure 5: Environmental impact of the construction and end scenarios of the timber building 
It is obvious that the environmental benefits provided by each end scenario are capable of reducing the total environmental impact of the construction of the timber building to a significant degree. The scenario which provides the highest environmental benefits is the reuse scenario, which maximized the benefits derived from the reuse of the timber components. Their reuse completely removes the need for additional manufacturing processes that would increase the environmental impact caused. Even with recycling, although the environmental benefits are also considerably high, the need for processing the retrieved wood and re-manufacturing it into new wood products eliminates the quantities of raw materials, yet still requires a series of manufacturing processes. As expected, the incineration scenario provides reduced environmental benefits due to the burden caused by the burning of the timber components.

The fact that all three end scenarios provide significant environmental benefits is mainly attributed to the recycling of the steel wall and roof panels which is taken account. This can be clearly observed in Figure 6, in which the flow of environmental impact caused throughout the life cycle of the timber building is presented. The reuse end scenario is used for this illustration and the recycling of the steel panels is the same in each of the three end scenarios.

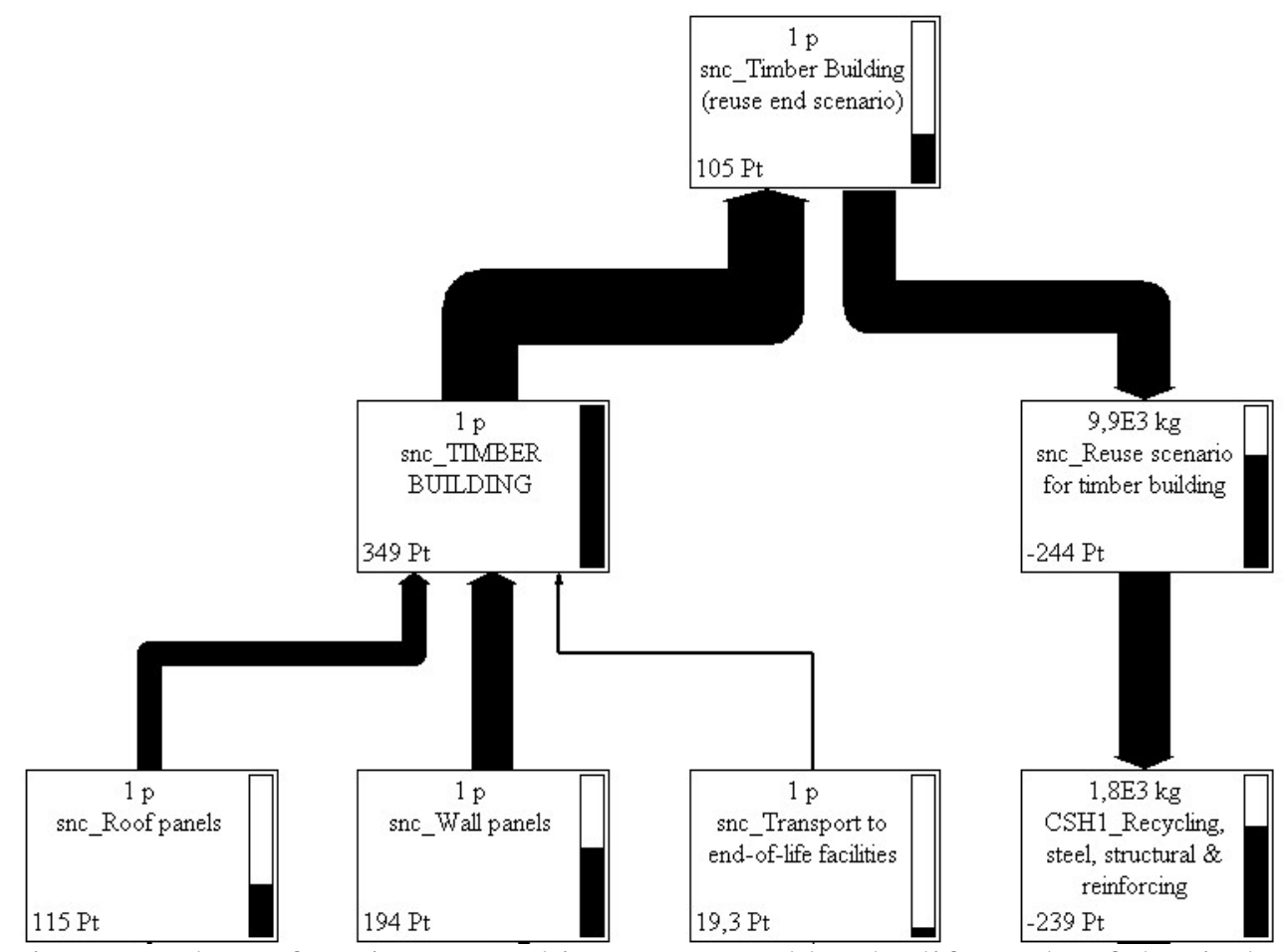

Figure 6: Flow of environmental impact caused by the life cycle of the timber building (reuse scenario)

\section{Conclusions}

The purpose of the current research was to investigate the sustainability potential of timber as a construction material through the quantification of the environmental 
impact caused throughout the life cycle of timber buildings. The calculations were based on a ground-floor timber building constructed of a series of load-bearing frames. A LCA analysis was conducted and the life cycle stages taken into account included the acquisition of raw materials and energy, the transport of the materials to the site and their handling at the end of the building's service life. For the later, three end scenarios were developed -recycling, reuse and incineration.

The results concerning the main materials and processes required for the construction of the timber building showed that the largest environmental impacts are caused by the steel cladding materials, while the structural timber causes a much smaller impact. This was attributed to the fact that structural timber elements require minimum processing in comparison to other construction materials. It was therefore suggested that timber products should be considered preferable, as their utilization decreases the total environmental impact, subsequently increasing the overall sustainability of a construction project. In regard to the type of environmental impact caused, it was shown that the construction of the timber building primarily affects the quality of natural resources, human health and climate change.

The results concerning the end scenarios showed that that the environmental benefits provided are capable of reducing the total environmental impact of the construction of the timber building to a significant degree. The highest environmental benefits are provided by the reuse of the timber components as the need for additional manufacturing processes is completely removed.

\section{Acknowledgments}

This research has been co-financed by the European Union (European Social Fund ESF) and Greek national funds through the Operational Program "Education and Lifelong Learning" of the National Strategic Reference Framework (NSRF) Research Funding Program: ARCHIMEDES III. Investing in knowledge society through the European Social Fund.

\section{References}

[1] United Nations, Our Common Future, Report of the World Commission on Environment and Development. Available at: http://www.undocuments.net/wced-ocf.htm Accessed on 02 April 2012, (1987)

[2] United Nation (1992) Rio Declaration on Environment and Development. Available at: http://www.unep.org/Documents.Multilingual/Default.asp?documentid=78\&articleid=1163 Accessed on 02 April 2012, (1992)

[3] Eurostat, Waste statistics. Available at http://epp.eurostat.ec.europa.eu/statistics_explained/index.php/Waste_statistics Accessed on 5 April 2012, (2011)

[4] D.N. Kaziolas, I. Zygomalas, G. E. Stavroulakis and C. C. Baniotopoulos, "Environmental sustainability assessment methodologies for steel and timber structures”. In: Proceedings of the 9th WSEAS International Conference on Energy, Environment, Ecosystems and Sustainable Development (EEESD’13), pp. 37-42, Lemesos - Cyprus, 2013. 
[5] O. Ortiz, F. Castells, and G. Sonnemann, "Sustainability in the construction industry: A review of recent developments based on LCA". Construction and Building Materials, 23, 28-39, 2009.

[6] A.C. Coelho, J.M. Branco, H. Gervásio, "Life-cycle assessment of a singlefamily timber house". 1st International Conference on Building Sustainability Assessment BSA 2012, 23-25 May, Porto, 533-542, 2012.

[7] A. Dodoo A, L. Gustavsson, R. Sathre R., "Carbon implications of end-of-life management of building materials”. Resources, Conservation \& Recycling 53(5): 276-286, 2009.

[8] B. Lim, S. Brown and B. Schlamandinger, "Carbon accounting for forest harvesting and wood products”. Environmental Science \& Policy 2 (2), 207216, 1999.

[9] F. Werner and K.Richter K., "Wooden building products in comparative LCA: A Literature review”. Int. J. LCA 12(7):470-479, 2007.

[10] B. Lippke, J. Wilson, J. Perez-Garcia, J. Bowyer, and J. Meil, "CORRIM: Life-cycle environmental performance of renewable building materials". Forest Products Journal 54(6):8-19, 2004.

[11] A. Buchanan, and S. Levine, "Wood based building materials and atmospheric carbon emissions”. Environmental Science \& Policy (2), 427-437, 1999.

[12] The Eco-indicator 99, "A damage oriented method for Life Cycle Impact Assessment-Methodology Report 17 April 2000- Second edition, 2000 